Rev.MVZ Córdoba 21(2):5441-5448, 2016. ISSN: 0122-0268

COMMUNICATION BRIEF

\title{
Roadkill hotspots in a protected area of Cerrado in Brazil: planning actions to conservation
}

\section{Zonas de alto impacto de atropellamientos en un área protegida de Cerrado (Brasil): planeando acciones para la conservación}

\author{
Bruno H Saranholi, ${ }^{1 *}$ M.Sc. Mariano M Bergel, ${ }^{2}$ Esp, Paulo HP Ruffino, ${ }^{2}$ M.Sc, \\ Karen G Rodríguez-C, ${ }^{1}$ M.Sc, Lucas A Ramazzotto, ${ }^{1}$ Biotec, Patrícia D de Freitas, ${ }^{1}$ Ph.D, \\ Pedro M Galetti Jr, ${ }^{1}$ Ph.D.
}

${ }^{1}$ Universidade Federal de São Carlos, Depto. de Genética e Evolução, CEP 13565-905 São Carlos-SP, Brasil. ${ }^{2}$ Instituto Florestal, Secretaria do Meio Ambiente do Governo do Estado de São Paulo, CEP: 02377-000, Brasil. Correspondence: bruno.saranholi@gmail.com

Received: March 2015; Accepted: September 2015.

\begin{abstract}
Objective. Here we aimed to identify the main points of animal death by roadkill in the view of helping mitigation plans and reducing the impact over the local fauna of a protected area. Materials and methods. We surveyed the roads around a protected area of Cerrado (São Paulo, Brazil) from May 2012 to August 2013. We recorded the local of roadkills, biometric and morphologic data of the animals, and collected samples of tissue for molecular species confirmation. Results. Thirty-one roadkilled animals were registered, including threatened species: Leopardus pardalis; Cuniculus paca and Chrysocyon brachyurus. Most roadkills were represented by mammals $(54.8 \%)$ and reptiles $(38.7 \%)$, and the mortality rate was 1.46 animals $/ \mathrm{km} /$ year. Three roadkill hotspots were detected, suggesting that they were important points of animal crossing, probably because of the existence of natural remnant vegetation and intersection of roads by riparian vegetation. Conclusions. This work provided strong evidence of the most critical points where mitigation strategies should be immediately implemented and highlighted the importance of detecting roadkill hotspots and the species or taxonomic groups more affected, helping to elaborate effective actions that can improve fauna conservation.
\end{abstract}

Key words: Fragmentation, mitigation, road ecology, road mortality, wildlife conservation; (Sources: Agrovoc, $C A B$ ).

\section{RESUMEN}

Objetivo. Identificar los principales puntos donde mueren animales para proponer planes de mitigación. Materiales y métodos. Se recorrieron las vías alrededor de una área protegida de Cerrado (São Paulo, Brasil) entre Mayo de 2012 y Agosto de 2013. Se registró el lugar del atropellamiento, datos biométricos y morfológicos de los animales y se colectaron muestras de tejido para la confirmación molecular de la especie. Resultados. Se registraron 31 animales atropellados (muertos), incluyendo especies amenazadas: Leopardus pardalis; Cuniculus paca y Chrysocyon brachyurus. La mayoría de los atropellamientos fueron representados por mamíferos $(54.8 \%)$ y reptiles $(38.7 \%)$ y la tasa 
de mortalidad fue de 1.46 animales/km/año. Fueron detectados tres hotspots de atropellamiento, sugiriendo que son puntos importantes en la probabilidad de cruce de animales, debido a un remanente de vegetación natural y la intercepción de la carretera con bosques de galería. Conclusiones. Este trabajo proporciona fuerte evidencia de los puntos más críticos donde las estrategias de mitigación deben ser implementadas inmediatamente y resalta la importancia de detectar hotspots de atropellamiento, las especies y los grupos taxonómicos más afectados ayudando a elaborar acciones efectivas que pueden mejorar la conservación de la fauna.

Palabras clave: Conservación de la vida silvestre, ecología, fragmentación, mortalidad, reducción (Fuentes: Agrovoc, CAB).

\section{INTRODUCTION}

Roads may represent an important factor of economic and social development for a region $(1,2)$. However, their presence may result in strong environmental impact, such as the removal of natural vegetation to their construction (3), isolation of the natural populations and loss of animals by roadkill (4).

It is estimated about one million of vertebrates annually killed by vehicles on roads in the United States (4). In Brazil, roadkill estimations are still scarce (5).

Therefore, fauna roadkill is recognized as the main cause of vertebrate mortality, surpassing even the hunting (6). Some studies also suggest that the presence of roads can represent a major threat to wildlife when near to conservation areas due to the high abundance of species and individuals (7).

The reduction of natural populations by roadkill increases their risk of extinction (2). Estimating and monitoring this impact over the fauna is essential to propose mitigation actions (8). In this context, the molecular analysis is a powerful tool to correct species identification (9) and it could be used whenever morphological species identification is difficult.

In this work we surveyed roadkill vertebrates around a Cerrado protected area in Southeastern Brazil and identified roadkill hotspots, which could be used in mitigation plans in order to reduce the impact over the local fauna.

\section{MATERIAL AND METHODS}

Study site. Roadkills in two municipal wide-lane roads (Domingos Innocentini and Ayrton Senna roads) around an important area for Cerrado biome conservation (Itirapina city, São Paulo, Brazil) were surveyed. This area is one of the few remaining protected areas of this biome at São Paulo State where are located the Itirapina Ecological Station (IECS) and the Itirapina

\section{INTRODUCCIÓN}

Las carreteras pueden presentar un importante factor de desarrollo económico y social para una región $(1,2)$. Sin embargo, su presencia puede resultar en un fuerte impacto ecológico, como remoción de la vegetación natural para su construcción (3), aislamiento de las poblaciones naturales y pérdida de animales por atropellamientos (4).

Se estima que cerca de un millón de animales vertebrados muere atropellado anualmente en las carreteras de los Estados Unidos (4). En Brasil, estimativas de los animales atropellados todavía son escasas (5).

Por lo tanto, los atropellamientos de fauna son considerados como la principal causa de mortalidad de vertebrados, superando inclusive a la caza (6). Algunos estudios también sugieren que la presencia de carreteras cerca de áreas de conservación puede representar la mayor amenaza para la vida silvestre debido a la alta abundancia de especies e individuos (7).

La reducción de poblaciones naturales por atropellamientos aumenta su riesgo de extinción (2). Estimar y monitorear este impacto sobre la fauna es esencial para proponer acciones de mitigación (8). En este contexto, los análisis moleculares son una poderosa herramienta para la correcta identificación de las especies (9) y puede ser utilizada inclusive cuando la identificación morfológica de las especies se dificulta.

En este trabajo se identificaron los vertebrados atropellados alrededor de un área protegida de Cerrado en el Suroriente de Brasil y se determinaron hotspots de atropellamientos, información que puede ser utilizada para planes de mitigación que busquen reducir el impacto sobre la fauna local.

\section{MATERIALES Y MÉTODOS}

Sitio de estudio. Se registraron los atropellamientos de vertebrados en dos carreteras municipales pavimentadas de calzada simple 
Experimental Station (IES), surrounded by a buffer area comprised by Cerrado and riparian vegetation. The IEcS $\left(22^{\circ} 11^{\prime} \mathrm{S}, 47051^{\prime} \mathrm{W}\right)$ covers 2300 ha with many threatened species, such as, maned wolf (Chrysocyon brachyurus), rhea (Rhea americana) and cougar (Puma concolor) (10). The IES ( $22^{\circ} 15^{\prime} \mathrm{S}, 47^{\circ} 45^{\prime} \mathrm{W}$ ) encompasses 3212 ha in which about 2000 ha are used for scientific research and cultivation of exotic vegetation (Pinus sp. and Eucalyptus sp.).

Data collection. The sampling sites were chosen considering the proximity to the protected area of Cerrado in Itirapina. We surveyed $12 \mathrm{~km}$ (seven $\mathrm{km}$ inside the protected area and five $\mathrm{km}$ in the buffer area) at the Ayrton Senna road and four $\mathrm{km}$ around the limits of the protected area at Domingos Innocentini road.

The roads were checked twice everyday during five days/week from May 2012 to August 2013. We registered the local of roadkills with a GPS, photographed the animals and registered biometric and morphologic data (paw size, tail size, weight) and sex. We also collected samples of tissue (muscle, skin or hair) in order to confirm molecularly the species identification and create of a genetic database for future molecular analyses. Threat status of species was categorized following the list of threatened fauna of São Paulo State (10).

Molecular species identification. DNA was extracted from tissue samples using fenolcloroformio protocol (11). The DNA integrity was verified using $1 \%(\mathrm{w} / \mathrm{v})$ agarose gel and the quantification was conducted with BioPhotometer (Eppendorf Corporation ${ }^{\circledR}$ ). We used 16S (12) and COI (13) universal primers to molecular species identification. The PCR (polymerase chain reaction) protocol was similar for both primer sets as it follows: $1 \mathrm{X}$ buffer tris- $\mathrm{KCl} 10 \mathrm{X}$ (Tris- $\mathrm{HCl}$ $200 \mathrm{mM} \mathrm{pH} 8.4$ and $\mathrm{KCl} 500 \mathrm{mM}$ ), $4 \mathrm{mM} \mathrm{MgCl}$, $0.25 \mathrm{mM}$ dNTPs, $0.3 \mathrm{pmol}$ of each primer, $1 \mathrm{U}$ Taq DNA Polymerase Platinum (Invitrogen) and $50 \mathrm{ng}$ of DNA template for a final volume of 25 $\mu$ l. The DNA amplifications were carried out in an Applied Biosystems Veriti ${ }^{\circledR}$ Thermal Cycler under the following conditions: $94^{\circ} \mathrm{C}$ for $4 \mathrm{~min}$, $35 \mathrm{cycles}$ at $94^{\circ} \mathrm{C}$ for $45 \mathrm{~s}, 50-51^{\circ} \mathrm{C}$ for $45 \mathrm{~s}, 72^{\circ} \mathrm{C}$ for $45 \mathrm{~s}$ and a final extension at $72{ }^{\circ} \mathrm{C}$ for $10 \mathrm{~min}$.

PCR products sequencing was performed in an automated sequencer (ABI3730XL, Applied Biosystems) by Macrogen, Inc., in South Korea (www.macrogen.com). The nucleotide sequences were compared to databases from NCBI (National Center for Biotechnology Information) and BOLD (Barcode of Life Data Systems) to the species identification.
(Domingos Innocentini y Ayrton Senna) alrededor de una importante área para la conservación del Bioma Cerrado (Itirapina, São Paulo, Brasil). Esta área es una de los pocos remanentes protegidos del Bioma en el estado de São Paulo y en ella se localiza la estación ecológica de Itirapina (IEcS) y la estación experimental de Itirapina (IES), rodeada por un zona de amortiguamiento compuesta por Cerrado y bosques de galería. La IEcS $\left(22^{\circ} 11^{\prime} \mathrm{S}, 47051^{\prime} \mathrm{W}\right)$ comprende 2300 ha habitadas por muchas especies amenazadas como el lobo de crin (Chrysocyon brachyurus), el ñandú común (Rhea americana) y el puma (Puma concolor) (10). La IES (22015'S, 47045'W) engloba 3212 ha en las cuales cerca de 2000 ha son utilizadas para investigaciones científicas y el cultivo de vegetación exótica (Pinus sp. and Eucalyptus sp.).

Colecta de datos. Los sitios de colecta fueron escogidos considerando la proximidad con el área protegida de Cerrado en Itirapina. Se recorrieron $12 \mathrm{~km}$ (siete $\mathrm{km}$ dentro del área protegida y cinco km en la zona de amortiguamiento) en la carretera Ayrton Senna y cuatro km alrededor de los límites del área protegida en la carretera Domingos Innocentini.

Las carreteras fueron recorridas dos veces cada día durante cinco días/semana desde Mayo de 2012 hasta Agosto de 2013. Se registró el lugar del atropellamiento mediante un GPS, los animales fueron fotografiados y sus datos biométricos, morfológicos (tamaño de la pata, tamaño de la cola, peso) y el sexo fueron registrados. También se colectaron muestras de tejido (músculo, piel o pelo) para la confirmación molecular de la identificación de la especie y para la creación de una base de datos genética para futuros análisis moleculares. El estatus de amenaza de las especies se estableció siguiendo la lista de fauna amenazada del estado de São Paulo (10).

Identificación molecular de las especies. EI ADN fue extraído de las muestras de tejido utilizando el protocolo de fenol-cloroformo (11). La integridad de ADN fue verificada utilizando gel de agarosa al $1 \%$ y cuantificando en un Biofotómetro (Eppendorf Corporation ${ }^{\circledR}$ ). Se utilizaron los primers universales 165 (12) y COI (13) para la identificación molecular de las especies. El protocolo para PCR (polymerase chain reaction) utilizado fue similar para ambos primers: $1 \times$ buffer tris- $\mathrm{KCl} 10 \times$ (Tris- $\mathrm{HCl} 200 \mathrm{mM}$ $\mathrm{pH} 8.4$ y KCl $500 \mathrm{mM}), 4 \mathrm{mM} \mathrm{MgCl}, 0.25 \mathrm{mM}$ dNTPs, 0.3 pmol de cada primer, 1 U Taq DNA Polymerase Platinum (Invitrogen) y $50 \mathrm{ng}$ de ADN para un volumen final de $25 \mu \mathrm{l}$. La amplificación del ADN fue realizada en un Applied Biosystems 
Data analyzes. The frequency of roadkill was calculated dividing the number of killed animals by the number of kilometers covered during the whole study period.

The roadkills were plotted over the local road map using Siriema software (Spatial Evaluation of Road Morality Software) (14) to identify the hotspots of occurrences. We used the Ripley's $K$ statistics (15) to evaluate the non-random distribution of roadkills. Although the road linearization causes loss of dimensionality, with this transformation the formation of false clusters at the curves was prevented (14).

Influence of landscape characteristics on the roadkill hotspots was also evaluated. A land cover map of the studied area was constructed by using satellite images from Google Earth (16) and the Quantum GIS program (17) with five meters final resolution. The distance between a hotspot and its nearest land cover was calculated. Land cover was classified as natural vegetation (including Cerrado and riparian vegetation), river, lakes, sugar cane, silviculture, pastures and urbanized areas. The association between hotspot and land cover was tested by ANOVA and significant association was evaluated by Tukey test, after data log transformation.

Linear regression between the monthly average temperature obtained from the registers of Itirapina Ecological Station (IECS) and the number of roadkills per month, with log transformed data to fit the parametric tests requirements was also performed to investigate whether there are influence of the environmental temperature on number of roadkills.

\section{RESULTS}

We registered 31 roadkilled animals of 21 different species in 16 months (Table 1 ). From the total of species, Leopardus pardalis (vulnerable), Cuniculus paca (near threatened) and Chrysocyon brachyurus (vulnerable) were stated according to the list of threatened fauna of São Paulo State (10).

The mortality rate was 1.46 animals/km/year and three significant clusters of roadkill were detected in $0-1 \mathrm{~km}, 3-3.5 \mathrm{~km}$ and $13-14 \mathrm{~km}$ along the 16 $\mathrm{km}$ sampled (Figure. 1). In one of these points (0-1 km) for example, we registered seven roadkilled animals, which represents $22.6 \%$ of total records. Positive association between the presence of natural vegetation and roadkill hotspots $(p=0.009)$ was detected.
Veriti $\circledast$ siguiendo estas condiciones: $94^{\circ} \mathrm{C}$ por 4 min, 35 ciclos a $94^{\circ} \mathrm{C}$ por $45 \mathrm{~s}, 50-51^{\circ} \mathrm{C}$ por 45 $\mathrm{s}, 72^{\circ} \mathrm{C}$ por $45 \mathrm{~s}$ y una extensión final a $72^{\circ} \mathrm{C}$ por $10 \mathrm{~min}$.

Los productos del PCR fueron analizados en un secuenciador automático (ABI3730XL, Applied Biosystems) por la empresa Macrogen, Inc., en Corea del Sur (www.macrogen.com). Las secuencias nucleotídicas fueron comparadas con secuencias de las bases de dados del NCBI (National Center for Biotechnology Information) y BOLD (Barcode of Life Data Systems) para la identificación de las especies.

Análisis de datos. La frecuencia de los atropellamientos fue calculada dividiendo el número de animales atropelladas por el número de kilómetros recorridos durante el periodo completo del estudio.

Los puntos de atropellamientos fueron plotados sobre un mapa de la carretera utilizando el software Siriema (Spatial Evaluation of Road Morality Software) (14) para identificar los hotspots de los eventos. Se utilizó el estadístico K de Ripley (15) para evaluar la distribución no-aleatoria de los atropellamientos. Además de la perdida de dimensionalidad causada por la linearización con esta transformación se previene la formación de falsos clusters en las curvas (14).

La influencia de las características del paisaje en los hotspots de atropellamientos también fue evaluada. Igualmente fue construido un mapa de cobertura con cinco metros de resolución final del área estudiada utilizando imágenes de satélite del Google Earth (16) y el programa Quantum GIS (17). La distancia entre el hotspot y la cobertura del paisaje más cercana fue calculada. Las coberturas del paisaje fueron clasificadas como: vegetación natural (incluyendo Cerrado y bosques de galería), ríos, lagos, cultivos de caña de azúcar, silvicultura, pastizales y áreas urbanas. La asociación entre el hotspot y la cobertura fue probada con ANOVA y su significancia fue evaluada con el test de Tukey después de una transformación de los datos.

Regresiones lineares entre el promedio mensual de temperatura obtenida a partir de los registros de la estación ecológica de Itirapina (IEcS) y el número de atropellamientos per mes fueron realizadas para evaluar si hay influencia de la temperatura ambiental sobre el número de atropellamientos, para esto los datos fueron log-transformados para ajustarlos a los requerimientos de los testes paramétricos. 


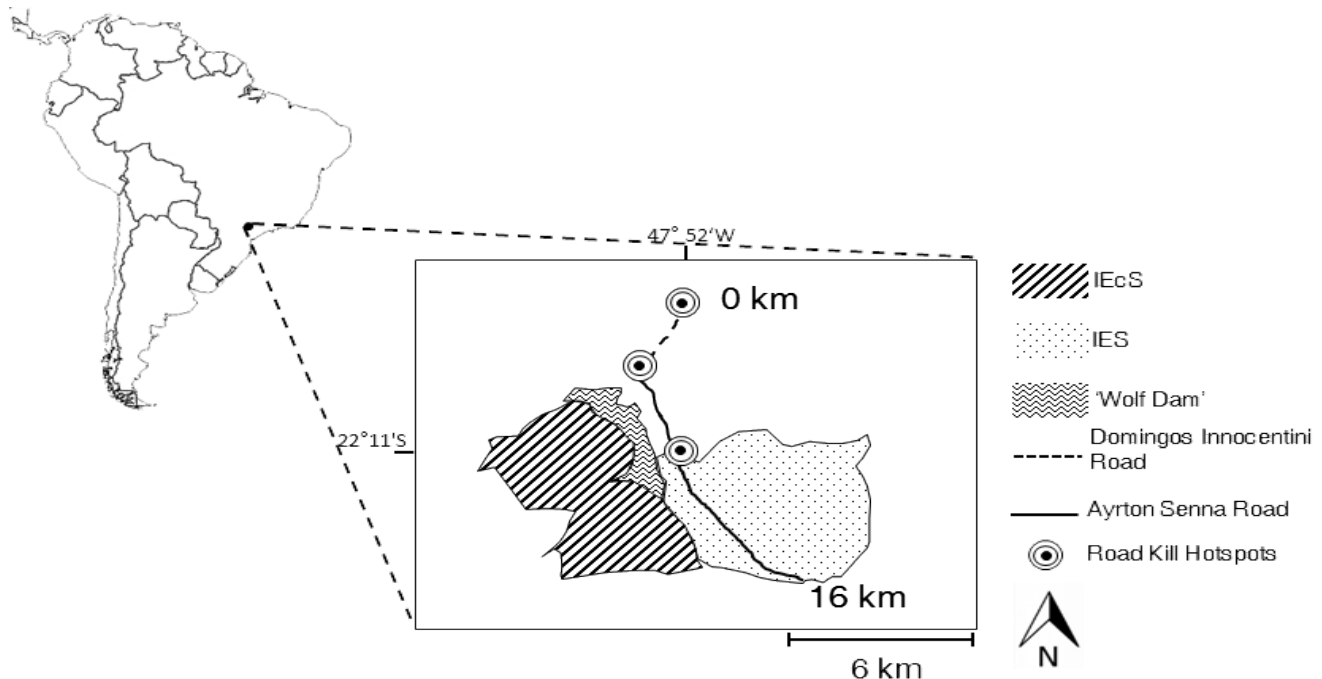

Figure 1. Geographical location and detail of roadkill hotspots. IEcS (Itirapina Ecological Station); IES (Itirapina Experimental Station).

Table 1. Species and number of roadkilled individuals.

\begin{tabular}{|c|c|c|}
\hline Species & Common Name & Individuals \\
\hline \multicolumn{3}{|l|}{ Mammal } \\
\hline Leopardus pardalis & Ocelot & 1 \\
\hline Didelphis albiventris & Opossum & 1 \\
\hline Lepus europaeus & European hare & 1 \\
\hline Cuniculus paca & Spotted paca & 2 \\
\hline Coendou prehensilis* & Porcupine & 2 \\
\hline Chrysocyon brachyurus & Maned wolf & 2 \\
\hline Myocastor coypus & River rat & 1 \\
\hline Procyon cancrivorus & Raccon & 1 \\
\hline Dasypus novemcinctus & Nine-banded armadillo & 2 \\
\hline Sylvilagus brasiliensis & Tapeti & 2 \\
\hline Mazama gouazoubira & Brown brocket & 1 \\
\hline Cerdocyon thous* & Crab-eating fox & 1 \\
\hline \multicolumn{3}{|l|}{ Reptile } \\
\hline Ameiva ameiva & Giant ameiva & 1 \\
\hline Tupinambis merianae & Black-and-white tegu & 3 \\
\hline Crotalus durissus & Cascabel rattlesnake & 3 \\
\hline Boa constrictor* & Boa constrictor & 1 \\
\hline Sibynomorphus mikanii & Neuwied's tree Snake & 1 \\
\hline Philodryas olfersii* & $\begin{array}{c}\text { South American green } \\
\text { racer }\end{array}$ & 1 \\
\hline Erythrolamprus aesculapii* & False coral & 2 \\
\hline \multicolumn{3}{|l|}{ Bird } \\
\hline Cariama cristata & Red-legged seriema & 1 \\
\hline Polyborus plancus & Caracara & 1 \\
\hline Total of species & & 22 \\
\hline Total of individuals & & 31 \\
\hline
\end{tabular}

* Species that could not be confirmed molecularly.

The number of roadkills was higher according to the environmental temperature increasing $\left(F_{1.14}=8.39, R^{2}=0.375, p=0.012\right)$. The months with higher mean temperature (October and November 2012 , with $26.1^{\circ} \mathrm{C}$ and $25.1^{\circ} \mathrm{C}$,

\section{RESULTADOS}

Se registraron 31 animales atropellados de 21 especies diferentes en 16 meses (Tabla 1). Del total de especies fueron clasificados conforme la lista de fauna amenazada del estado de São Paulo (10) Leopardus pardalis (vulnerable), Cuniculus paca (casi amenazado) y Chrysocyon brachyurus (vulnerable).

La tasa de mortalidad fue de 1.46 animales/ $\mathrm{km} / \mathrm{año}$ y tres clusters de atropellamientos significativos fueron detectados; entre 0-1 km, entre 3-3.5 km y entre 13-14 km a lo largo de los $16 \mathrm{~km}$ muestreados (Figura 1). En uno de estos puntos $(0-1 \mathrm{~km})$ por ejemplo, se registraron siete animales atropellados, $22.6 \%$ del total de los registros. Fueron detectadas asociaciones positivas entre la presencia de vegetación natural $y$ los hotspots de atropellamiento $(p=0.009)$.

El número de atropellamientos fue mayor conforme el aumento de la temperatura ambiental $\left(F_{1,14}=8.39, R^{2}=0.375, p=0.012\right)$. Los meses con temperatura media mayor (Octubre y Noviembre 2012 , con $26.1^{\circ} \mathrm{C}$ y $25.1^{\circ} \mathrm{C}$, respectivamente) presentaron 8 animales atropellados, lo que representa un $25.8 \%$ del total de atropellamientos.

\section{DISCUSIÓN}

La fauna local que habita el área estudiada se encuentra sobre una fuerte presión por los atropellamientos. La tasa de mortalidad observada (1.46 animales/km/año) fue mucho más alta que la reportada por Da Cunha et al (18) en un área no protegida de Cerrado $(0.014$ 
respectively) presented eight roadkilled animals, which represent $25.8 \%$ of total roadkilling.

\section{DISCUSSION}

The local fauna inhabiting the area here studied is over a strong roadkill pressure. The mortality rate observed (1.46 animals/km/year) was much higher than reported by Da Cunha et al. (18) in an unprotected area of Cerrado (0.014 animals/ $\mathrm{km}$ /year), suggesting that road impact is more drastic around protected area where fauna abundance is expectedly higher. This observed difference in roadkill intensity makes important to survey and elaborate specific mitigation actions for each target location.

A large number of records and species were here detected, including species with great ecological importance, such as the maned wolf and the ocelot. Since these species are top predators, they are vital in maintaining the equilibrium of other species populations and the loss of individuals can result in ecological consequences to the local fauna, such as disequilibrium on herbivorous density and consequently on plant community (19). It is imperative to highlight that the number of roadkilled animals may be much higher than reported here because some animals may not be detected or carcass could possibly be removed due to weather conditions, for example.

Mammal and reptile species represented $54.8 \%$ and $38.7 \%$, respectively, of the roadkilled animals. Only five species could not be confirmed by molecular analysis probably due to bad conservation of tissue samples, which impaired the DNA amplification in PCR, although these seven individuals could be morphologically identified. In contrast, the success in identifying most of samples demonstrated the great potential of the DNA analysis, mainly for those specimens hard to identify morphologically because of their level of degradation or when the taxonomic group needs a specialist for correct identification.

Roadkill number was higher during the warmer months and such outcome was mainly influenced by Tupinambis merianae roadkills, probably due to the animal movement for reproduction often associated to the warmer temperatures season (20). Then, strategies to facilitate or avoid road crossing by animals should be more effective if they take into account the known reproductive periods that turns the animals more vulnerable to the roadkills.

The three detected roadkill hotspots were associated to the natural vegetation presence, which suggests that they are important points of animales/km/año), sugiriendo que el impacto de las carreteras es más drástico alrededor de áreas protegidas, donde abundancia de fauna esperada es mucho más alta. La diferencia observada en la intensidad de los atropellamientos muestra la importancia de estudiar y elaborar acciones específicas de mitigación para cada lugar.

Un gran número de registros y especies fueron detectados, incluyendo especies con gran importancia ecológica, como el lobo de crin y el ocelote. Una vez que estas especies son predadores superiores ellos son vitales para mantener el equilibrio de poblaciones de otras especies y la pérdida de individuos puede resultar en consecuencias ecológicas para la fauna local como un desequilibrio en la densidad de los herbívoros y seguidamente en la comunidad de las plantas (19). Es importante destacar que el número de animales atropellados puede ser mucho más alto que lo reportado pues algunos animales no son detectados, o los restos pueden ser removidos debido a las condiciones climáticas, por ejemplo.

Las especies de mamíferos y reptiles representaron $54.8 \%$ y $38.7 \%$ de los animales atropellados respectivamente. Solo cinco especies no pudieron ser confirmadas por los análisis moleculares, debido al pésimo estado de conservación de las muestras de tejido, impidiendo la amplificación del ADN en el PCR, aunque los siete individuos pudieron ser identificados morfológicamente. Sin embargo, el éxito en la identificación de la mayoría de las muestras demostró el gran potencial de los análisis de DNA, principalmente para individuos difíciles de identificar morfológicamente por su nivel de degradación o en grupos taxonómicos en los cuales es necesario un especialista para la correcta identificación.

El número de atropellamientos aumentó durante los meses calientes, este resultado pudo ser influenciado principalmente por los atropellamientos de Tupinambis merianae, debido probablemente al movimiento de los animales para reproducción frecuentemente asociado a las temporadas de temperaturas más altas (20). De este modo, estrategias que faciliten o eviten el paso de los animales serán más efectivas si se consideran los periodos de reproducción que hacen los animales más vulnerables a los atropellamientos.

Los tres hotspots detectados fueron asociados a la presencia de vegetación natural, lo que sugiere que son puntos de cruce importantes para los animales. En el hotspot 0-1 km, el principal lugar de atropellamientos, remanentes 
animal crossing. At the $0-1 \mathrm{~km}$ hotspot, the main local of roadkills, natural remnant of Cerrado on both sides of the road is predominant. At the others two hotspots, the road intersects small streams with riparian vegetation. It is suggested that more roadkills near to natural vegetation than near to sugar cane plantations and pasture, is associated to preferential animal moving through this type of land cover. Open areas usually offer lesser resources for the animals, besides risk to be exposed is increased. Similar results were also found by Bueno et al (21) showing strong correlation between landscape characteristics on capybara (Hydrochoerus hydrochaeris) roadkill on other Brazilian highway.

Such studies demonstrate the importance of monitoring wildlife in linear infrastructure, especially around protected areas, since roadkill may represent a strong threat to the local fauna. The roadkill hotspots determination is the first step to reduce these impacts on wildlife. A number of strategies can be efficient to reduce or prevent animal roadkills: Wildlife crossing as underpass tunnels, overpasses with fences to drive the animals as well as, velocity control sensor and warning traffic signs at these hotspots, contributing to reduce deaths on the road.

In sum, our work provides a strong evidence of the most critical points where the mitigation strategies should be implemented immediately to reduce the roadkills in the studied area. This study highlights the importance of detecting the main points of roadkill and the more affected species or taxonomic groups, supporting the elaboration of effective actions that can improve the fauna conservation.

\section{Acknowledgements}

This work was supported by the SISBIOTA - Top predator network. The authors thank Conselho Nacional de Desenvolvimento Científico e Tecnológico (CNPq) and Fundação de Amparo à Pesquisa do Estado de São Paulo (FAPESP) for financial support. naturales de Cerrado predominan en ambos costados de la carretera. En los otros hotspots, la carretera es interceptada por pequeños ríos con bosques de galería. Esto sugiere que la mayoría de los atropellamientos cerca de vegetación natural que de plantaciones de caña de azúcar y pastizales está asociado a el movimiento preferencial de los animales a través de este tipo de cobertura del paisaje. Las áreas abiertas usualmente ofrecen menos recursos para los animales además que el riesgo por estar expuesto aumenta. Resultados similares fueron también encontrados por Bueno et al (21) mostrando fuerte correlación entre las características del paisaje sobre los atropellamientos de chigüiro (Hydrochoerus hydrochaeris) en otra autopista brasilera.

Estos estudios demuestran la importancia de monitorear la fauna en infraestructuras lineares, especialmente alrededor de áreas protegidas, puesto que los atropellamientos pueden representar una fuerte amenaza para la fauna local. Determinar los hotspots es el primer paso para reducir los impactos sobre la vida silvestre $(9,27)$. Un número de estrategias puede ser eficiente para reducir 0 prevenir atropellamientos de animales: Ecoductos como pasos subterráneos, pasos a desnivel con vallas para conducir a los animales así como sensores para control de la velocidad y señales de tránsito de advertencia en estos hotspots permitirán la reducción de muertes en las carreteras.

En síntesis, en este trabajo se proporciona una fuerte evidencia de los puntos más críticos donde estrategias de mitigación deben ser implementadas inmediatamente para reducir los atropellamientos en el área estudiada. Este estudio resalta la importancia de detectar puntos principales de atropellamiento y las especies o los grupos taxonómicos más afectados, ayudando a la elaboración de medidas eficaces que pueden mejorar la conservación de la fauna.

\section{Agradecimientos}

Este trabajo fue financiado por la red SISBIOTA Predadores superiores. Los autores agradecen al Conselho Nacional de Desenvolvimento Científico e Tecnológico (CNPq) y a la Fundação de Amparo à Pesquisa do Estado de São Paulo (FAPESP) por el apoyo económico. 


\section{REFERENCES}

1. Bager A, Fontoura V. Evaluation of the effectiveness of a wildlife roadkill mitigation system in wetland habitat. Ecol Eng 2013; 53:31-38.

2. Coffin AW. From roadkill to road ecology: A review of the ecological effects of roads. J Transp Geogr 2007; 15(5):396-406.

3. Do Prado TR, Ferreira AA, Guimarães ZFS. Efeito da implantação de rodovias no cerrado brasileiro sobre a fauna de vertebrados. Acta Sci Biol Sci 2007; 28(3):237-241.

4. Forman RTT, Beckmann JP, Clevenger AP, Huijser M, Hilty JA. Safe passages: highways, wildlife, and habitat connectivity. Island Press; 2012.

5. Coelho IP, Kindel A, Coelho AVP. Roadkills of vertebrate species on two highways through the Atlantic Forest Biosphere Reserve, southern Brazil. Eur J Wildl Res 2008; 54(4):689-699.

6. Jaarsma $\mathrm{CF}$, van Langevelde $\mathrm{F}$, Botma $\mathrm{H}$. Flattened fauna and mitigation: traffic victims related to road, traffic, vehicle, and species characteristics. Transp Res part D Transp Environ 2006; 11(4):264-276.

7. Garriga N, Santos $X$, Montori A, Richter-Boix A, Franch M, Llorente GA. Are protected areas truly protected? The impact of road traffic on vertebrate fauna. Biodivers Conserv 2012; 21(11):2761-2774.

8. Fahrig L. Rethinking patch size and isolation effects : the habitat amount hypothesis. J Biogeogr 2013; 1649-1663.

9. Balkenhol N, Waits LP. Molecular road ecology: exploring the potential of genetics for investigating transportation impacts on wildlife. Mol Ecol 2009;18(20):4151-64.

10. Bressan PM, Kierulff MCM, Sugieda AM. Fauna ameaçada de extinção no estado de São Paulo: Vertebrados. Zoólogico de São Paulo, Secretaria do Meio Ambiente, Governo de São Paulo; 2009.
11. Green MR, Sambrook J. Molecular cloning: a laboratory manual. Cold Spring Harbor Laboratory Press New York; 2012.

12. Palumbi S. Simple fool's guide to PCR; 1991.

13. Folmer $\mathrm{O}$, Black $M$, Hoeh $W$, Lutz $R$, Vrijenhoek R. DNA primers for amplification of mitochondrial cytochrome c oxidase subunit I from diverse metazoan invertebrates. Mol Mar Biol Biotechnol 1994; 3(5):294-299.

14. Coelho AVP, Coelho IP, Kindel A. SIRIEMA. Spat Eval Road Mortal Software User's Guid; 2006.

15. Levine N. CrimeStat: A Spatial Statistical Program for the Analysis of Crime Incidents. Encyclopedia of GIS SE - 229. Springer US; 2008.

16. Google Inc, Google Inc. (2005). Google Earth. Mountain View, CA. 2005.

17. QGis DT. Quantum GIS geographic information system. Open Source Geospatial Found Proj. 2011.

18. Da Cunha HF, Moreira FGA, de Sousa Silva S. Roadkill of wild vertebrates along the GO-060 road between Goiânia and Iporá, Goiás State, Brazil. Acta Sci Biol Sci 2010; 32(3):257-263.

19. Ripple WJ, Beschta RL. Large predators limit herbivore densities in northern forest ecosystems. Eur J Wildl Res 2012; $58(4): 733-742$.

20. Chamut S, Jahn GA, Arce OEA, Manes ME. Testosterone and reproductive activity in the male Tegu lizard, Tupinambis merianae. Herpetol Conserv Biol 2012; 7(3):299-305.

21. Bueno C, Faustino MT, Freitas S. Influence of landscape characteristics on capybara roadkill on highway BR-040, southeastern Brazil. Oecologia Aust 2013; 17(2):320-327. 